\title{
Editorial: Branding and the new global village?
}

As the Journal of Leisure Property moves into its second volume, readers will have noticed that the focus of the Journal is shifting. From the line-up of the editorial board to the origins of the papers, the Journal is now placing itself far more as a truly international offer, developing ideas from around the globe with one common theme: how best to develop, manage and appraise leisure properties. This issue alone brings contributions from the USA, Australia and the UK together with a paper that considers management contracts for hotels in the Middle East. A truly global spread.

It is perhaps very timely that the Journal rises to the global challenge, given recent events on the world stage. These have brought into very sharp focus the political and economic interaction between countries, and nowhere is this more evident than in relation to the leisure and tourism markets. From airlines to hospitality and visitor attractions, businesses, already fragile in the light of a softening world economy, have seen turnover fall to the point, in some cases, of complete collapse. In the UK alone, an estimate by the English Tourism Council of losses in the order of some $£ 2.5$ bn for 2001 is not proving unrealistically pessimistic. In relation to the major hotel trade, the international consultants Jones Lang La Salle point to a decline in internal rates of return, consequent on 11 September.

Shocking though recent events have been and however clearly they have brought into focus the volatility of the leisure industries, neither global interdependence nor volatility in leisure returns are new phenomena. Indeed, both characteristics go to the very heart of the industry and affect the way in which properties are managed and operated.

\section{A GLOBAL INDUSTRY}

It was almost 20 years ago that Sampson ${ }^{1}$ used the term 'the new nomads' for people who 'seem more devoted to their company than their country' and for whom 'their habitat seems to belong to no nation'. So, nothing new in the global business. To Sampson, this was a depressing and arid picture, one of business people inhabiting 'InterContinentals, Hiltons or Sheratons which appear interchangeable' and 'neatly segregated from the real countryside'. The image created was one of a drab uniformity of global proportions within a Fordist tradition.

So, in the post-Fordist world, has the predicted direction of a global hotel market catering for a nomadic community of business 
people and pleasure-seekers indeed been realised in further convergence? The evidence is mixed. Global business may lead to international boards creating brands that are recognised worldwide but, perhaps picking up on the didactic of Shumacher in his quest for subsidiarity ${ }^{2}$ and respect for the individual, the global convergence at board level has been associated with divergence and market segmentation at a local level. A case of 'think global: act local'. Hence, within the hospitality business, the segmentation of the market in terms of the offer (from budget to five star to 'aparthotels' and 'boutiques') has enabled some individuality to be retained in the actual customer experience.

But is this structuring into discrete 'offers' enough? Can the ambition of competitive advantage born of economic efficiencies of scale maintain individuality to appeal to the volatile nature of the pleasure-seeker? To the business man or woman, predictability and familiarity are key requirements; so the replicated offer, well presented and instantly recognisable by brand, complies with the nature of the market demand. But for the tourist seeking adventure and an experience that is different, the cultural globalisation of the branded offer, vividly described by Toynbee ${ }^{3}$ as a 'milkshake of the mind, spilling across frontiers, cultures and languages', is not the solution. Given the downturn in the markets, the challenge to hotel and attraction providers is to ensure that the offer is constantly refreshed and provides sufficient stimulus to encourage the maybereluctant consumer to spend.

This reinforces the message of the importance of management of the asset and this is a theme that is explored in different contexts within this issue. Goddard and Standish-Wilkinson in their paper on hotel management contracts in the Middle East provide a detailed analysis of the issues facing the hotel management contractor in an increasingly competitive market-place. Within the Middle East, the split between ownership and operator, manifested in the preferred structure of management contracting, has arisen due to both legal constraints and the inherent risk perceived in the market. This, they argue, has now led to contracts that leave little room for manoeuvre by the operators, who are faced with increasingly low base fees and higher incentive bonuses. While this may encourage efficiency, they conclude that it is driving out all but the largest operators, who are best placed to inject equity within the agreed financial arrangements.

\section{BUILDING THE BRAND}

Implicit within Goddard and Standish-Wilkinson's paper is the idea that the corporate imperative is still towards the increasing domination of large brands - albeit that the brand itself is differentiated. Branding is perhaps the dominant characteristic of the hotel offer, but it extends far beyond the hospitality market to other aspects of the leisure property industry, from entertainment to culture and even conservation. 
But is this a matter of 'building the brand', or creating the individualised offer and turning that into a recognisable, if one-off, 'brand'? Consideration of the creation of a brand and its underlying relationship to value is undertaken by Cowan in her paper 'Leisure design and the art of branding'. Cowan takes the whole concept of brand image beyond that of brand awareness and brand loyalty to a refinement connected with the idea of refreshment and novelty. In this, she makes an intriguing proposition about the way in which art and design can build into an expected 'offer' an element of surprise that provides the consumer with 'added value' something they do not expect. This message reinforces the need, inherent within all entertainment and hospitality businesses, to recognise the discretionary nature of spending. If value for money and enjoyment of the product are not achieved, neither is repeat business. There are very few businesses that can survive on the single-trip market, hence the need for entrepreneurial enterprise and refreshment of product.

The issue of branding is not exclusively one that is reserved for commercial enterprise. Archer and Wearing, writing in relation to national parks in Australia, recognise that branding and marketing extend to social provision. For public providers, whose objectives lie not in maximising private shareholder wealth but in supplying the education, cultural and nature conservation needs to optimise social returns to more diverse stakeholders, the issues are different. Nevertheless, they argue, the proper image promotion and marketing (in short the branding) of a national park can create additional income in the hands of park managers such that they can better fulfil their social and conservation objectives. They do, however, acknowledge that tensions exist between meeting the need of natural habitat conservation and accommodating increased visitor numbers, a problem that is all too familiar to managers of national parks in other countries. Nonetheless, they argue, a net benefit can be realised from shifting the mentality from one of interpretation to one of marketing.

\section{VALUING THE BRAND}

The primary objective of creating a brand is to generate identity, loyalty and repeat business, and with it increased profitability. Taken to its extreme, the corporate value may be argued to lie as much - or indeed more - in the brand than in the product, as eloquently argued by Klein ${ }^{4}$ in her thought-provoking book No Logo.

This value creation or enhancement associated with brand development leads to issues which must be addressed by the consultancy team charged with assessing real estate values, both for the market and for the balance sheet. Nilsson et al. in their paper 'Valuing hotels as business entities' provide a useful analysis of appraisal methodology, in both the USA and the UK, and in so doing conclude that the primary driver of hotel value lies in capitalisation of future net incomes. This is not a surprising 
conclusion, given the drivers of hotel ownership, but the lack of an internationally recognised single approach to the appraisal of hotels and other trading entities is a challenge that has still to be fully taken up. While their paper does point out the issues that evaluating brands can raise within the appraisal process, it does not specifically address the relationship between brand and property value. This is not surprising, as no consensus exists. Yet it is one of the greatest challenges that face the appraisal profession. If the value of hotels and other trading property lies within the inherent ability of the asset to generate business, how far is that inherent ability combined with the entrepreneurial skills of the operatorparticularly when that operator is a brand leader?

So the issue becomes a question of how far does brand value drive real estate asset value? Is it something that can, and should, be separated out? If it is, what level of management efficiency should be assumed? This challenge is one that contributors to and readers of the Journal of Leisure Property are encouraged to address.

\section{SUMMARY}

So a new economically and politically uncertain time is being entered, in which the signs are that the leisure property industry, from hotel operators to golf course developers, will have to be ever more creative, whether they operate in the public or the private sector. In so doing, the need to balance the individual offer with a worldwide brand appeal may grow ever more important. Hopefully, the Journal of Leisure Property will continue to be the place to air the debate.

Sarah L. Sayce

December 2001

\section{References}

1. Sampson, A. (1982) A New Anatomy of Britain, Hodder and Stoughton, London, p. 419.

2. Schumacher, E. F. (1973) Small is Beautiful, Blond and Biggs, London.

3. Toynbee, P. (2000) 'Who's afraid of global culture?', in Hutton, W. and Giddens, A. (Eds) On the Edge, Jonathan Cape, London, pp. 191-212.

4. Klein, N. (2000) No Logo, Flamingo, London. 